\title{
前立腺癌に抢ける酸性フォスファターゼの研究
}

\author{
第 3 報 ヒト前立腺酸性フォスファターゼに対する特異的抗体の作製
}

長崎大学医学部泌尿器科学教室 森 下 直 由
(主任 : 近藤厚教授)

\section{STUDIES ON ACID PHOSPHATASE IN PROSTATIC CANCER}

III. Production of Specific Antibody against Human Prostatic Acid Phosphatase

Naoyoshi Morishita

Department of Urology, Nagasaki University School of Medicine

(Director: Prof. A. Kondo)

1. Prostatic acid phosphatase (PAP) was purified about 130 fold from human seminal plasma by DEAE Sephadex A-50 ion-exchange column chromatography and Sephacryl S-200 gel chromatography.

2. Rabbits were immunized with the purified PAP as antigen, and anti-PAP antiserum was obtained. This antiserum was fractionated through a Sephadex G-25 column and the obtained IgG fraction was passed through the immunoadsorbent column coupled to normal female serum.

3. This rabbit anti-PAP IgG was tested by double immunodiffusion, and precipitation lines were observed against seminal plasma, prostatic extract, sera of patients with prostatic cancer, and liver extract of a patient with prostatic cancer. Immunoelectrophoretic examination revealed the single precipitation line in anodic side against the liver extract, but in cathodic side against the other samples.

4. By indirect immunofluorescence technique using the rabbit anti-PAP IgG, fluorescence was demonstrated in the section of prostate, but no staining in sections of liver, spleen, kidney, and pancreas.

要旨: 精漿から前立腺酸性フォスファターゼを約130倍に精製し, ウサギに免疫し抗血清を作製した。この抗 血清を IgG 分画とした後, 正常女性血清をカップリングしたaffinity chromatographyにて精製した。この抗 体は Ouchterlony 法では精漿, 前立腺抽出液, 前立腺癌患者血清のほかに前立腺癌患者の肝抽出液との間に 完全に一致する沈降線を認めた. 免疫電気泳動上, 肝抽出液では陰極側に単一の酵素活性を有する蛋白沈降線 を認めるのに対し，他のものでは陽極側に見られた. ウサギ抗 PAP IgG を用いた間接蛍光抗体法では, 前 立腺組織のみが反応し, 肝, 脾, 腎, 膵では陰性であつた。

\section{緒言}

酸性フォスファターゼ (ACP) は各種蔵器に存在して おり, 前立腺はその活性の高い臓器の 1 つである. ACP 活性は前立腺癌に拈ける marker enzyme の1つであり, その特異的測定法の確立が望まれている. 前報1飞て前 立腺組織抽出液と精浆の ACP には disc electrophoresis 上, 同様の isoenzyme ACP-2 があることを示した. 組 織化学的にも前立腺の分泌性 ACP は, phosphorylcholine を基質として使用すれば前立腺に特異的であるという報
告2)もあるため, 精浆の ACP を精製し, 得られたもの を前立腺酸性フォスファターゼ (P-ACP) として, ウサ ギに免疫して抗血清を作製した.ささらにこの抗血清を用 いて, 蛍光抗体法を含めた臓器特異性の検討を行つた.

\section{実験材料および実験方法}

\section{I. 実験材料}

1. 精浆, 正常成人男子より得られた精夜を使用まで $-20^{\circ} \mathrm{C}$ に保存した。

2. ヒト組織, 前立腺癌 (stage D) による死亡 3 時 
間後に剖検で得られた腎臓, 肝臓, 膵臟, 脾臓, 前立腺 癌組織と慢性腎不全で死亡した女性の肝臓を用いた。 た前立腺腺腫は前立腺肥大症より核出したものを用い た。

\section{II 。実験方法}

1. 前立腺酸性フォスファターゼの精製, 保存精液を 解凍, 遠沈して得られた精浆を, DEAE Sephadex A-50 ion-exchange column chromatography $と て 200 \mathrm{mM} \mathrm{NaCl}$ 含有 tris-HCl buffer で溶出される分画を得た. PBS に て充分透析後, 濃縮し Sephacryl S-200 $(2.6 \times 90 \mathrm{~cm})$ に て2 回 gel chromatography を行い, 得られた酵素活性 ピーク部を透析し, $1 \mathrm{mg} / \mathrm{ml}$ まで濃縮し $-20^{\circ} \mathrm{C} て ゙$ 涷結保 存した。

2. 酥素活性測定法, p-nitrophenyl phosphate を基質 とする Bessey-Lowry 法3゙により測定した. 酔素活性は 1 分間に生成する p-nitrophenol の $\mu \mathrm{mol}(\mu \mathrm{mol} / \mathrm{min})$ で示した。

3. 蛋白質の定量, Lowry らの方法 ${ }^{4)}$ 準じて行っ た. カラム溶出液の蛋白量は $280 \mathrm{~nm}$ の吸光度により測 定した。

4. disc polyacrylamide gel electrophoresis (PAGE), Reisfeld ら ${ }^{5)}$ の方法に準じて $\mathrm{pH} 4.0$ 用ゲルを調整し, $\mathrm{pH} 4.5$ 用電極槽緩衝液を用い, 定電流 $4 \mathrm{~mA} /$ カラム, 120 分間泳動した。蛋白染色はアミド黒 10Bを用い, ACP 活性染色は $\alpha$-naphthyl phosphate-fast garnet GBC salt をそれぞれ $1 \mathrm{mg} / \mathrm{ml}$ 含む $0.1 \mathrm{M}$ ammonium acetate buffer $\left(\mathrm{pH} \mathrm{5.0)}\right.$ 中 $37^{\circ} \mathrm{C}$ で反応させ染色し， 7 \%酢酸中 で保存した.

5. 抗ヒト P-ACP 抗血清の作製, 精製した P-ACP 抗原液と等量の Freund's complete adjuvant とを混和 し, ウサギの背部に皮下注 2 回 ( 1 週間隔): その後 2 週目より毎週静注（計 5 回）し, 最終注射の10日後に 䅡動脈より全採血して血清を分離した。得られた抗血
清は56 ${ }^{\circ} \mathrm{C} ， 30$ 分で非働化した. Sephadex G-25にて粗 $\gamma$ globulin とした後, CNBr-activated Sepharose 4B に常 法にて正常女性血清蛋白を結合させたもので affinity chromatography を行い，抗血清を作製した。

6. 免疫電気泳動, Agarose $1 \%$ の割合に veronal $\mathrm{HCl}$ buffer (pH 8.2) に溶解し, ゲル板を作製し, 定 電流 $2 \mathrm{~mA} / \mathrm{cm}, 90$ 分泳動後, 室温で抗ヒト P-ACP 免疫 ウサギ血清と反応させた.

7. Ouchterlony 法, Agarose を1。0\%の割合に PBS に溶解し, ゲル板を作製し, 室温で抗ヒト P-ACP ウサ ギ血清と反応させた.

8。 监光抗体法（間接法）

ヒト組織を䖺光抗体法用組織切片とし, 精製抗血清を のせ incubate, 次いで洗浄後 FITC ラベル抗ウサギ globulin ヤギ血清をのせ incubate 後蛍光顕微鏡にて観 察した.

\section{実験結果}

I ，前立腺酸性フォスファターゼの精製

前立腺酸性フォスファターゼの精製度は, Table 1 に 示すように回収率 $37.4 \%$ ，約130倍に精製された標品を 得た. 精製過程は Fig. 1 に示すごとくであるが, 最終 的には $280 \mathrm{~nm}$ に打ける吸光度と酵素活性は symmetric であった. しかし disc PAGE では本来の ACP-2 活性 部位とは別に蛋白のバンドがみられた（Fig. 2).

II. 抗とト P-ACP 血清の藏器特異性

得られた抗ヒト P-ACP 血清は免疫電気泳動にて陽極 側に ACP 活性のない蛋白沈降線が観察されたが，女性 血清による affinity chromatography 後は ACP 活性を もつ蛋白沈降線のみとなつた (Fig. 3). Ouchterlony 法 で観察すると精製 P-ACP, 前立腺癌, 腺腫抽出液, 前 立腺癌患者血清と特異的に反応するほかに, 前立腺癌 患者の肝抽出液との間にも精製 P-ACP と完全に一致す る沈降線を認めた (Fig. 4). しかし女性の肝抽出液と

Table 1 Activity and protein acounted for at each step of the purification procedu:e

\begin{tabular}{l|r|r|r|r}
\hline \multicolumn{1}{c|}{ Purification Step } & $\begin{array}{c}\text { Protein, } \\
(\mathrm{mg})\end{array}$ & $\begin{array}{c}\text { Total } \\
\text { activity * }\end{array}$ & $\begin{array}{l}\text { Specific **} \\
\text { activity }\end{array}$ & $\begin{array}{c}\text { Recovery, } \\
(\%)\end{array}$ \\
\hline 1. Seminal plasma & 2,405 & 22,166 & 9.2 & 100.0 \\
\hline 2. DEAE Sephadex & 68.6 & 18.166 & 264.8 & 81.9 \\
\hline 3. First Sephacryl S 200 & 29.4 & 9,666 & 328.7 & 43.6 \\
\hline 4. Second Sephacryl S 200 & 7.0 & 8.300 & $1,177.3$ & 37.4 \\
\hline
\end{tabular}

*: micromoles of substrate hydralyzed per minute : activity per mg. of protein 
Fig. 1 Chromatography on Sephacryl S-200 (2.6× $100 \mathrm{~cm}=490 \mathrm{ml}$ ) of (A) seminal plasma, (B) $1 \mathrm{st}$ Sephacryl S-200, (C) 2nd Sephacryl S-200, and (D) purified prostatic acid phosphatase; eluant PBS $(9 \mathrm{ml} / \mathrm{hr})$. The dashed curve represents the activity of acid phosphatase.

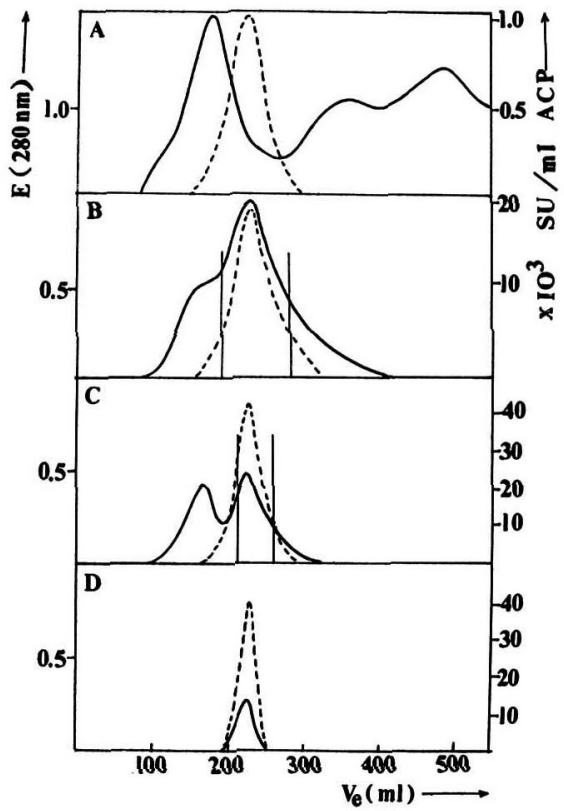

Fig. 2 Disc polyacrylamide gel electrophoresis of prostatic acid phosphatase. After electrophoresis. the gel was stained for protein (top) or acid phosphatase (bottom).

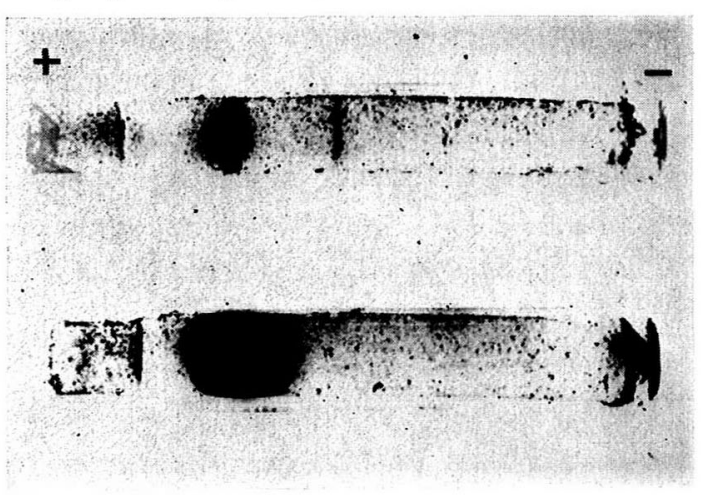

は反応 しなかつた，免疫電気泳動法 では前立腺組織抽 出液, 精製 P-ACP, 前立腺癌患者血清 が陽極側に泳動 されるのに対し，肝抽出液では逆に陰極側に泳動され (Fig. 5), 抗原性に関与しない部分が異なっていること を示した。
Fig. 3 Immunoelectrophoresis of prostatic acid phosphatase, before (A) and after (B, C) affinity chromatography. The plates were stained for protein (A, B) and acid phosphatase (C).
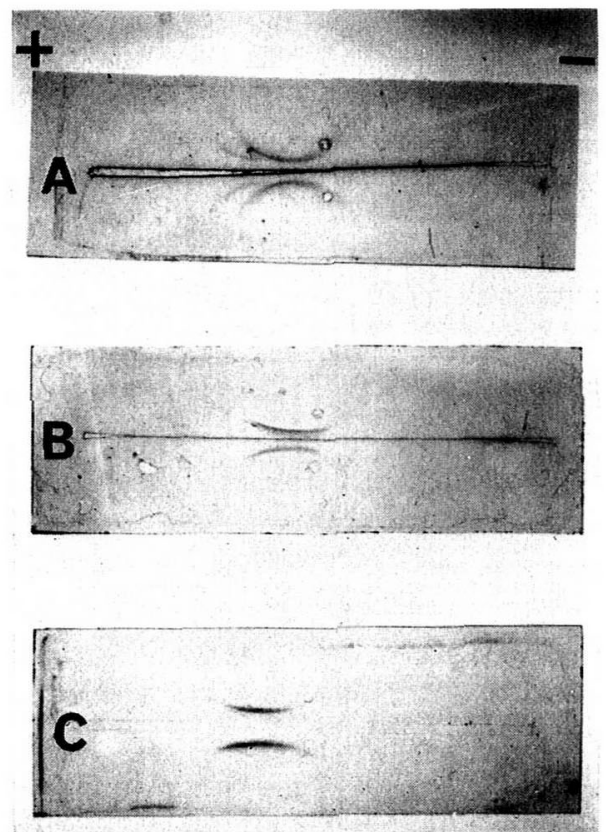

Fig. 4 Gel immunodiffusion analysis of prostatic acid phosphatase (acid phosphatase stain)

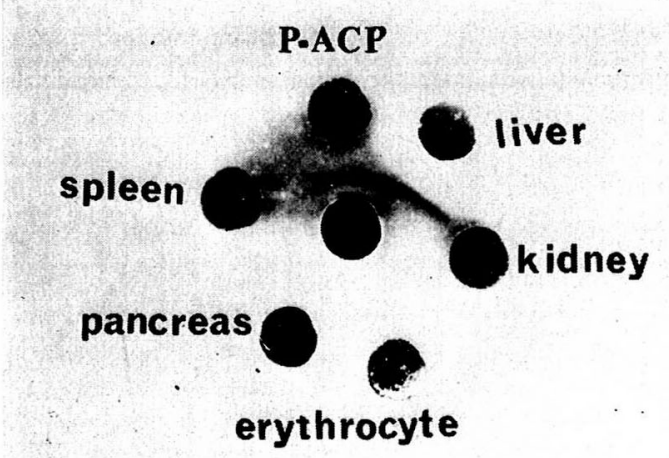

III. 䖢光抗体法

前立腺癌組織のみが反応し，肝，脾，腎，膵では陰性 であつた.

\section{考察および総括}

精浆より分離精製した P-ACP をウサギに免疫して得 た抗血清を女性血清にて吸収すると，免疫学的に精浆， 前立腺抽出液, 前立腺癌患者血清との間に酵素活性を有 
Fig. 5 Immunoelectrophoresis of prostatic acid phosphatase (upper half) and liver extract (lower half). After electrophoresis, antiserum was added to the trough and incubated for 24 hours at room temperature. The plate was stained for acid phosphatase

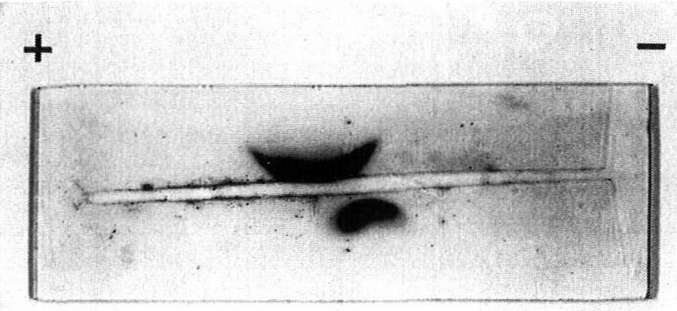

Fig. 6 Indirect immunofluorescence photomicrograph of section of prostatic carcinoma

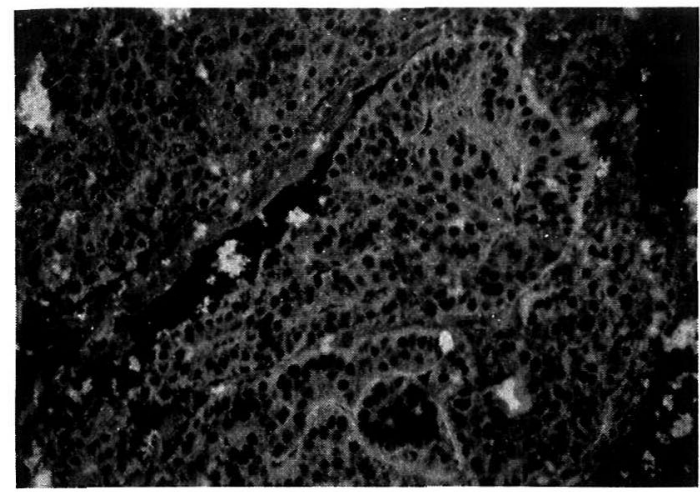

ナる蛋白沈降線を認めるほか，前立腺癌患者の肝抽出液 にも酵素活性を有する蛋白沈降線を認めたが，兔疫電気 泳動では前者が陽極側へ泳動されるのに対し，後者では 陰極側へ泳動された. 前立腺癌患者の膵, 腎, 脾抽出 液, 女性肝抽出液, 正常男女血清との間に蛋白沈降線は 認めなからた，文性の肝抽出液と交叉しない原因として は，PAP 抗原量が少ないか，皆無であることが考方ら れる. 女性肝に PAP が存在しないと与るなら, 前立腺 癌患者の血清 PAP が䯩い場合に, 朋にシアル酸量の異 なる PAP と同一抗原性をもつ ACP を含有していると 思われる。しかし radioimmunoassay に括ける訮，膵抽 出液との抗原交叉性あるい:膵癌組織での PAP 産生 ${ }^{6)}$ が報告されており，肝組織に PAP があることも否定で きないこ饥は $\mathrm{ACP}$ が細胞特異性をもち，前立腺酸性 フォスファターゼは他臟器由来の ACP とは免疫学的交 叉反応は示さないといら報告 ${ }^{7)}$ に反する. 前報 ${ }^{1)}$ に示し
たように前立腺抽出液には扣もに ACP-2 と ACP-4 が あり，neuramidase を作用させるとすべて ACP-4 の位

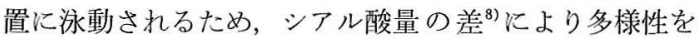
示すとされている，画者の抗原性は同一であり，弪抽出 液の ACP-4 は neuramidase では不変であるので，免疫 学的交叉反応を示してもよいと思われる。もし正常朋抽 出液中に P-ACP を含有するのであれば，正常血清 ACP 活性に有意の性差がみられないことの説明になるかも知 れない。

蛍光抗体法 ${ }^{910)}$ によると前立腺癌組織のみが反心し, 前立腺癌患者の訮組織で监光を認めなかったのは，抗原 量または $\mathrm{ACP}$ 局在に問題があると推測される，前立腺 癌組織では基底膜付近に监光が認められるが，ホルモン 療法の影響あるいは抗体の不純性が原因かも知れない。

精製した P-ACP で免疫されたこの抗血清は，前立腺 癌患者の肝 ACP と交义反応を示すとはいえ, 前立腺癌 患者で counter immunoelectrophoresis, radioimmuroassay を行えば特異的な相関が期待される。

\section{結語}

1. 精浆より約130倍に精製した前立腺酸性つィス ファターゼをウサギに免疫して抗血清を得た。

2. 女性血清による affinity chromatography にて精 製した抗血清は，Ouchterlony 法にて精浆，前立腺抽出 液, 前立腺癌患者血清のほかに前立腺癌患者の肝抽出液 との間に完全に一致する沈降線を認めた，免疫電気泳動 上，肝は陰極側へ，他は陽極側へ単一の沈降線を認め た.

3. 蛍光抗体法（間接法）では, 前立腺癌組織のみが 反応し, 肝, 脾, 腎, 猝では陰性であつた。

稿を終るにあたり, 御指導, 御校閲を賜つた近藤厚教 授，ならでに值接御指導を頂いた斉藤泰助教授に深甚な る謝意を表するとともに御協力を頂いた関連病院の諸先 生ならびに教窒員各位に感謝いたします。

\section{文献}

1) 森下直由：前立腺癌における酸性フォスフっ ターゼの研究第 1 報。各種組織抽出液の酸性 フォスフォターゼ・アイソザイムについて、日 泌尿会誌, 揭载予定.

2) Seligman, A.M., Sternbergen, N.J., Paul, B.D., Freedman, A.E., Shannon, W.A., Wasserkrug, H.L., Plapinger, R.E. and Lynm, D.: Design of spindle poisons activated specifically by prostatic acid phosphatase (PAP) and new methods for PAP cytochemistry. Cancer Chemother. Rep., 59, 233-242, 1975. 
3) Bessey, O.A., Lowry, O.H. and Brock, M.J.: A method for rapid determination of alkaline phosphatase with five cubic millimeters of serum. J. Biol. Chem., 164, 321-329, 1946.

4) Lowry, O.H., Rosenbrough, N.J., Farr, A.L. and Randall, R.J.: Protein measurement with the folin phenol reagent. J. Biol. Chem., 193, 265-275, 1951.

5) Reisfeld, R.A., Lewis, U.J. and Williams, D.E.: Disc electrophoresis of basic proteins and peptides on polyacrylamide gel. Nature, 195, 281-283, 1962.

6) Choe, B., Pontes, E.J., Rose, N.R. and Henderson, M.D.: Expression of human prostatic acid phosphatase in a pancreatic islet cell carcinoma. Invest. Urol., 15, 312-318, 1978.

7) Vihko, P., Sajanti, E., Janne, O., Peltonen,
L. and Vihko, R.: Serum prostate-specific acid phosphatase: Development and validation of a specific radioimmunoassay. Clin. Chem., 24, 1915-1919, 1978.

8) Dziembor, E., Gryszkiewitz, J. and Ostrowski, W.: Properties of neuraminidase-treated acid phosphatase of prostate. Acta Biochim. Pol., 18, 249-260, 1971.

9) Cocper, J.F., Foti, A. and Imfeld, H.: Production of specific antibody to purified prostatic acid phosphatase. Urol. Res., 4, 111-117, 1976.

10) Pontes, J.E., Choe, B., Rose, N. and Pierce, J.J.M.: Indirect immunofluorescence for identification of prostatic epithelial cells. J. Urol., 117, 459—463, 1977.

（1979年11月 8 日受付） 